Article

\title{
Th(IV) Adsorption onto Oxidized Multi-Walled Carbon Nanotubes in the Presence of Hydroxylated Fullerene and Carboxylated Fullerene
}

\author{
Jing Wang ${ }^{1}$, Peng Liu ${ }^{1}$, Zhan $\mathrm{Li}^{2}$, Wei Qi ${ }^{1}$, Yan Lu ${ }^{3}$, Wangsuo Wu ${ }^{1}$ * \\ 1 Radiochemistry Laboratory, School of Nuclear Science and Technology, Lanzhou University, \\ Lanzhou 730000, China; E-Mails: wangjing2010@ lzu.edu.cn (J.W.); liupeng08@1zu.edu.cn (P.L.); \\ qiwei20061987@126.com (W.Q.) \\ 2 Institute of Modern Physics, Chinese Academy of Sciences, Lanzhou 730000, China; \\ E-Mail: lizhaner@126.com \\ 3 China National Nuclear Corporation Lanzhou Uranium Enrichment Co., Ltd., Lanzhou 730000, \\ China; E-Mail: luyan08@1zu.edu.cn \\ * Author to whom correspondence should be addressed; E-Mail: wuws@lzu.edu.cn; \\ Tel. / Fax: +86-093-1891-3594.
}

Received: 15 June 2013; in revised form: 18 August 2013 / Accepted: 22 August 2013 /

Published: 17 September 2013

\begin{abstract}
The adsorption of Th(IV) onto the surface of oxidized multi-walled carbon nanotubes (oMWCNTs) in the absence and presence of hydroxylated fullerene $\left(\mathrm{C}_{60}(\mathrm{OH})_{n}\right)$ and carboxylated fullerene $\left(\mathrm{C}_{60}\left(\mathrm{C}(\mathrm{COOH})_{2}\right)_{n}\right)$ has been investigated. $\mathrm{C}_{60}(\mathrm{OH})_{n}$, $\mathrm{C}_{60}\left(\mathrm{C}(\mathrm{COOH})_{2}\right)_{n}$ and oMWCNTs have been chosen as model phases because of their representative in carbon nano-materials family. Adsorption experiments were performed by batch procedure as a function of contact time, $\mathrm{pH}$, ionic strength, and temperature. The results demonstrated that the adsorption of Th(IV) was rapidly reached equilibrium and the kinetic process could be described by a pseudo-second-order rate model very well. Th(IV) adsorption on oMWCNTs was dependent on $\mathrm{pH}$ but independent on ionic strength. Adsorption isotherms were correlated better with the Langmuir model than with the Freundlich model. The thermodynamic parameters calculated from temperature-dependent adsorption isotherms suggested that Th(IV) adsorption on oMWCNTs was spontaneous and endothermic. Compared with the adsorption of Th(IV) on the same oMWCNTs free of $\mathrm{C}_{60}(\mathrm{OH})_{n}$ or $\mathrm{C}_{60}\left(\mathrm{C}(\mathrm{COOH})_{2}\right)_{n}$, the study of a ternary system showed the inhibition effect of $\mathrm{C}_{60}(\mathrm{OH})_{n}$ at high concentration on the adsorption of $\mathrm{Th}(\mathrm{IV})$ in a $\mathrm{pH}$ range from neutral to slightly alkaline; whereas the promotion effect of $\mathrm{C}_{60}\left(\mathrm{C}(\mathrm{COOH})_{2}\right)_{n}$, even at its low
\end{abstract}


concentration, on Th(IV) adsorption was observed in acid medium.

Keywords: influence; $\mathrm{C}_{60}(\mathrm{OH})_{n} ; \mathrm{C}_{60}\left(\mathrm{C}(\mathrm{COOH})_{2}\right)_{n}$; Th(IV) adsorption; oMWCNTs

\section{Introduction}

Multiwalled carbon nanotubes (MWCNTs) have raised much interest during recent years due to their inherent extraordinary structural, mechanical, and electronic properties [1-3]. MWCNTs possess some highly desirable sorbent characteristics [4], which make them attractive for a variety of applications including radionuclide adsorption. Previous studies demonstrated that MWCNTs are the promising candidates in the field of chemical aspects of nuclear science and technology for the preconcentration and solidification of lanthanides and actinides from large volume of solutions [5-7]. Within the remarkable progress for industrial scale application, the toxicity of MWCNTs must be considered. Once they are released into the environment, the human health and environmental may suffer serious risks. CNTs can damage the plants, animals and human by entering the cells for their nanoscales [8-10]. The study showed that the toxicity of MWCNTs not only from itself but also from its adsorption substance. Therefore, understanding the adsorption of radionuclide on MWCNTs is crucial [11].

Thorium finds its extensive application as nuclear fuel in power plants and their main sources are soil, rocks, plants, sand and water. Nuclear spent fuels generally contain actinides like thorium, uranium and various fission products [12]. Th(IV) and its compounds are highly toxic that may cause acute toxicological effects for human leading to potential occupational carcinogens [13] and progressive or irreversible renal injury [14,15]. Thorium exists only stable as Th(IV) in solution, which is an important model element for other tetravalent actinides such as $\mathrm{Np}(\mathrm{IV}), \mathrm{U}(\mathrm{IV})$, and $\mathrm{Pu}(\mathrm{IV})$. It is also profit as a tracer for studying environmental important processes [16]. Based upon these importance of $\mathrm{Th}(\mathrm{IV})$, the determination of $\mathrm{Th}(\mathrm{IV})$ in environmental and biological samples is considerable potential as a tool for assessment of human exposure [15]. The fate and transport of $\mathrm{Th}(\mathrm{IV})$ in the environment is generally controlled by sorption reactions, complexation, colloid formation, etc. [17]. In recent years, the adsorption of $\mathrm{Th}(\mathrm{IV})$ on various materials has been studied extensively $[18,19]$. However, the adsorption behavior of actinide and lanthanide ions onto oMWCNTs is investigated in a limited number of studies [5-7,11,20,21], and the sorption mechanism is still unclear, especially in the presence of other nano-materials.

Fullerenes $\left(\mathrm{C}_{60}\right)$ is another kind of nanometer carbon materials whose discovery is earlier than carbon nanotubes. Due to its definite structure and $\pi$ electron character, $\mathrm{C}_{60}$ is very easy to form $\pi-\pi$ stacking interactions with another material equipped with aromatic rings [22,23], which may affect the adsorption of metal ions or organic matter on that material. Therefore, the research about the effect of fullerene on the adsorption of Th(IV) onto oMWCNTs is necessary. However, it is difficult to separate completely two kinds of carbon nano-materials in the identical phase, and to clarify their effect on the adsorptive interaction between carbon nano-materials and Th(IV). Herein, the author choose soluble fullerene to study its influence on the adsorption of Th(IV) onto oMWCNTs. It is essential to research 
the adsorption of soluble fullerene and Th(IV) on oMWCNTs for understanding the radionuclide pollution and the potential impact evaluation of CNTs on radionuclide behavior.

\section{Results and Discussion}

\subsection{Characterization of Purified oMWCNTs, $\mathrm{C}_{60}(\mathrm{OH})_{n}$ and $\mathrm{C}_{60}\left(\mathrm{C}(\mathrm{COOH})_{2}\right)_{n}$}

The transmission electron microscope (TEM, Hitachi Model H-600, Japan Hitachi company) was used to observe the changes in morphological features of oMWCNTs before and after two kinds of soluble fullerene adsorption. TEM image of oxidized MWCNTs (Figure 1a) display that carbon nanotubes have smooth surface and integrated hollow tubular structure. It can be seen from Figure $1 \mathrm{~b}$ that $\mathrm{C}_{60}(\mathrm{OH})_{n}$ particles (see the narrow present) spread heterogeneously on the surface of oMWCNTs for the $\mathrm{C}_{60}(\mathrm{OH})_{n}$-adsorbed oMWCNTs. Figure 1c indicates that $\mathrm{C}_{60}\left(\mathrm{C}(\mathrm{COOH})_{2}\right)_{n}$ particles does not attach with oMWCNTs.

Figure 1. Transmission electron microscope (TEM) images of (a) oxidized multi-walled carbon nanotubes (oMWCNTs); (b) $\mathrm{C}_{60}(\mathrm{OH})_{n}$-adsorbed oMWCNTs; (c) $\mathrm{C}_{60}\left(\mathrm{C}(\mathrm{COOH})_{2}\right)_{n}$-adsorbed oMWCNTs.

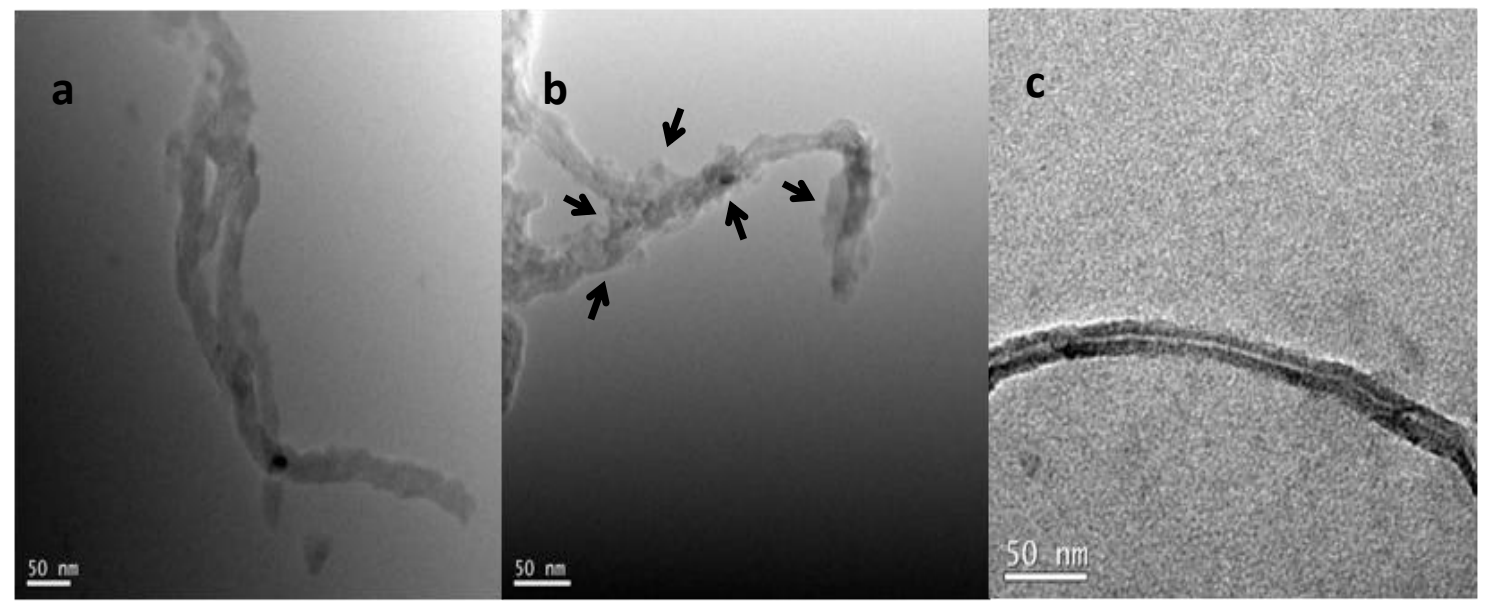

Fourier transform infrared (FTIR, Nexus670, Thermo Nicolet, American) technique was used in the analysis of the chemical surface groups of the adsorbents. Figure 2 illustrates the FT-IR spectrum of the oxidized carbon nanotubes. The peak at $3440 \mathrm{~cm}^{-1}$ is attributed to $-\mathrm{OH}$ stretching mode. The peaks at 2918 and $2849 \mathrm{~cm}^{-1}$ assigned to asymmetric and symmetric $-\mathrm{CH}$ stretching bands. The $\mathrm{C}=\mathrm{O}$ stretching vibrations peak are appeared at $1710 \mathrm{~cm}^{-1}$. The peak at 1625 and $1436 \mathrm{~cm}^{-1}$ assigned to $\mathrm{C}=\mathrm{C}$ stretching bands. The peak at $1513 \mathrm{~cm}^{-1}$ can be attributed the carboxylic and carboxylate anion stretching mode. The peak between 1100 and $1376 \mathrm{~cm}^{-1}$ is associated with $\mathrm{C}-\mathrm{O}$ stretching and $-\mathrm{OH}$ bending modes of alcoholic, phenolic and carboxylic groups [24,25].

Figure 3 shows the FT-IR spectrum of raw $\mathrm{C}_{60}, \mathrm{C}_{60}(\mathrm{OH})_{n}$ and $\mathrm{C}_{60}\left(\mathrm{C}(\mathrm{COOH})_{2}\right)_{n}$. For $\mathrm{C}_{60}(\mathrm{OH})_{n}$ (Figure 3b), the FTIR spectrum exhibit main peaks at wavenumbers near 3234, 1609, 1365 and $1086 \mathrm{~cm}^{-1}$, which are associated with $-\mathrm{OH}, \mathrm{C}=\mathrm{C}$ and $-\mathrm{C}-\mathrm{O}$ groups [26]. The bands at wavenumbers of $3439,1718,1201$ and $523 \mathrm{~cm}^{-1}$ for $\mathrm{C}_{60}\left(\mathrm{C}(\mathrm{COOH})_{2}\right)_{n}$ (Figure 3c) are indicative of the appearance of the stretching of hydroxyl $(-\mathrm{OH})$, carbonyl $(>\mathrm{C}=\mathrm{O})$ and carboxyl $(-\mathrm{C}-\mathrm{O})$ groups, respectively [27]. 
Figure 2. Fourier transform infrared (FTIR) spectra of oMWCNTs.

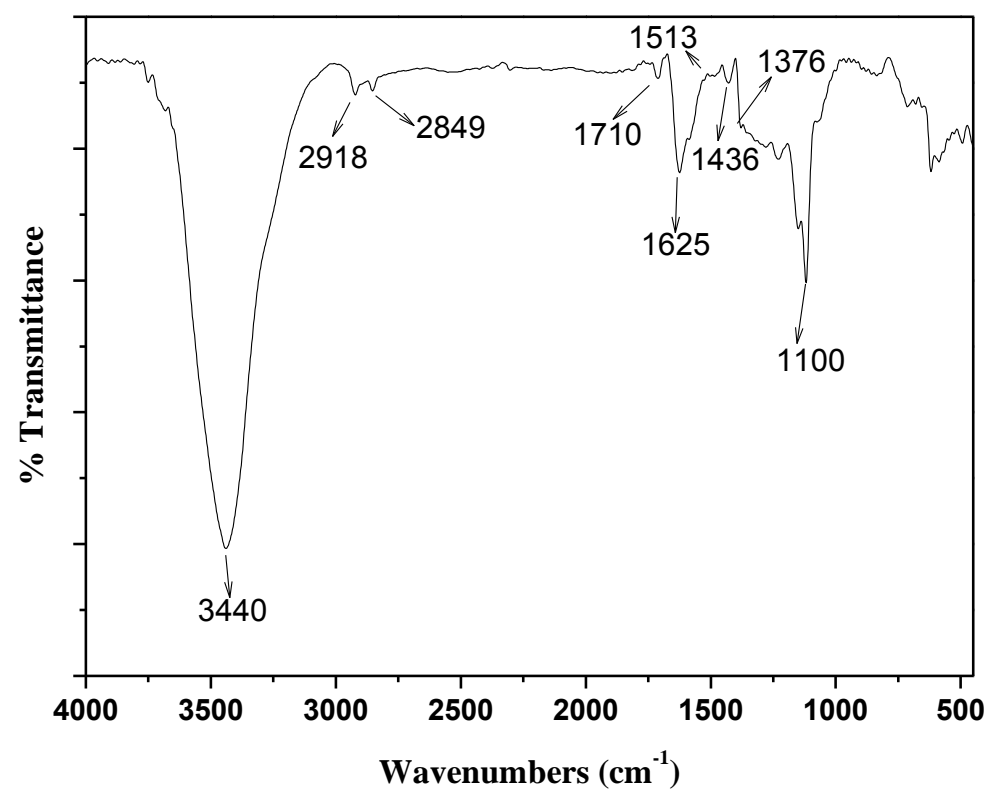

Figure 3. FTIR spectra of the samples: (a) raw $\mathrm{C}_{60} ;(\mathbf{b}) \mathrm{C}_{60}(\mathrm{OH})_{n} ;(\mathbf{c}) \mathrm{C}_{60}\left(\mathrm{C}(\mathrm{COOH})_{2}\right)_{n}$.

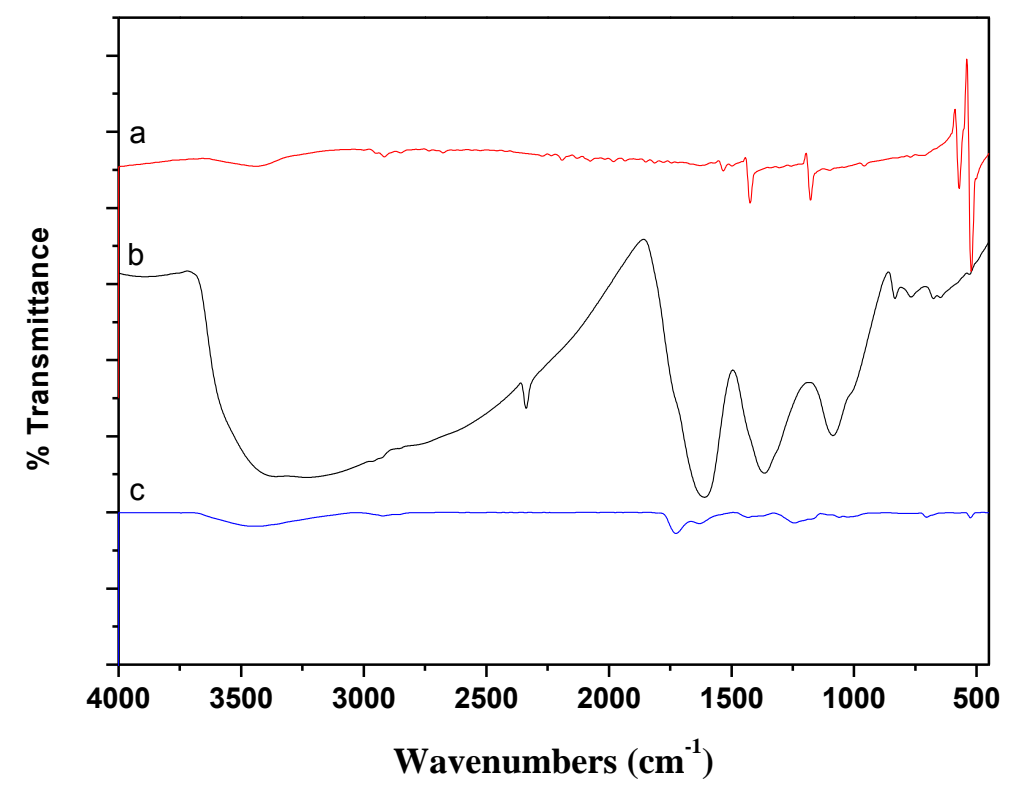

\subsection{Adsorption of Th(IV) onto oMWNTs Surface}

\subsubsection{The Sorption Kinetics}

The influence of contact time on the Th(IV) adsorption by oMWNTs was studied. The initial $\mathrm{Th}(\mathrm{IV})$ concentrations was $8.86 \times 10^{-5} \mathrm{~mol} / \mathrm{L}$ in the kinetic study. As seen from Figure 4, the uptake of $\mathrm{Th}(\mathrm{IV})$ onto oMWCNTs is rapid at the initial contact time, and then the adsorption equilibrium is reached within $3 \mathrm{~h}$. The quick adsorption of Th(IV) suggests that chemical adsorption rather than physical adsorption contributes to Th(IV) adsorption onto oMWCNTs surface [28]. To analyze the adsorption rate of Th(IV) onto oMWCNTs, the pseudo-second-order rate equation (Equation (1)) [29] is employed to simulate the kinetic adsorption data. Its general form is 


$$
\frac{t}{q_{t}}=\frac{1}{k_{0} q_{e}^{2}}+\frac{t}{q_{e}}
$$

where $q_{t}(\mathrm{mg} / \mathrm{g})$ is the amount of $\mathrm{Th}(\mathrm{IV})$ adsorbed on oMWCNTs at time $\mathrm{t}$ and $q_{e}(\mathrm{mg} / \mathrm{g})$ is the equilibrium sorption capacity. $k_{o}\left(\mathrm{~g} / \mathrm{mg} \cdot \mathrm{h}^{-1}\right)$ is the pseudo-second-order rate constant of sorption. The straight-line plots of $t / q_{t} v s$. $t$ (Figure4) is plotted and values of $k_{o}\left(1.81 \times 10^{-3} \mathrm{~g} / \mathrm{mg} \cdot \mathrm{h}^{-1}\right)$ and $q_{e}\left(6.44 \times 10^{-3} \mathrm{mg} / \mathrm{g}\right)$ are calculated from the intercept and slope of Equation (1). The correlation coefficient of the pseudo-second-order rate equation for the linear plot is 0.9999 , which suggests that the kinetic sorption can be described by the pseudo-second-order rate equation very well. Based on the above results, an equilibrium time is selected as $24 \mathrm{~h}$ for all subsequent batch experiments.

Figure 4. Effect of contact time on Th(IV) adsorption rate onto oMWCNTs and test of pseudo-second-order adsorption kinetics plot for $\mathrm{Th}(\mathrm{IV}), m / V=0.1 \mathrm{~g} / \mathrm{L}, T=25 \pm 1{ }^{\circ} \mathrm{C}$, $\mathrm{C}\left[\mathrm{Th}^{4+}\right]$ initial $=8.86 \times 10^{-5} \mathrm{~mol} / \mathrm{L}, I=0.01 \mathrm{~mol} / \mathrm{L} \mathrm{NaNO}_{3}, \mathrm{pH}=3.20 \pm 0.05$.

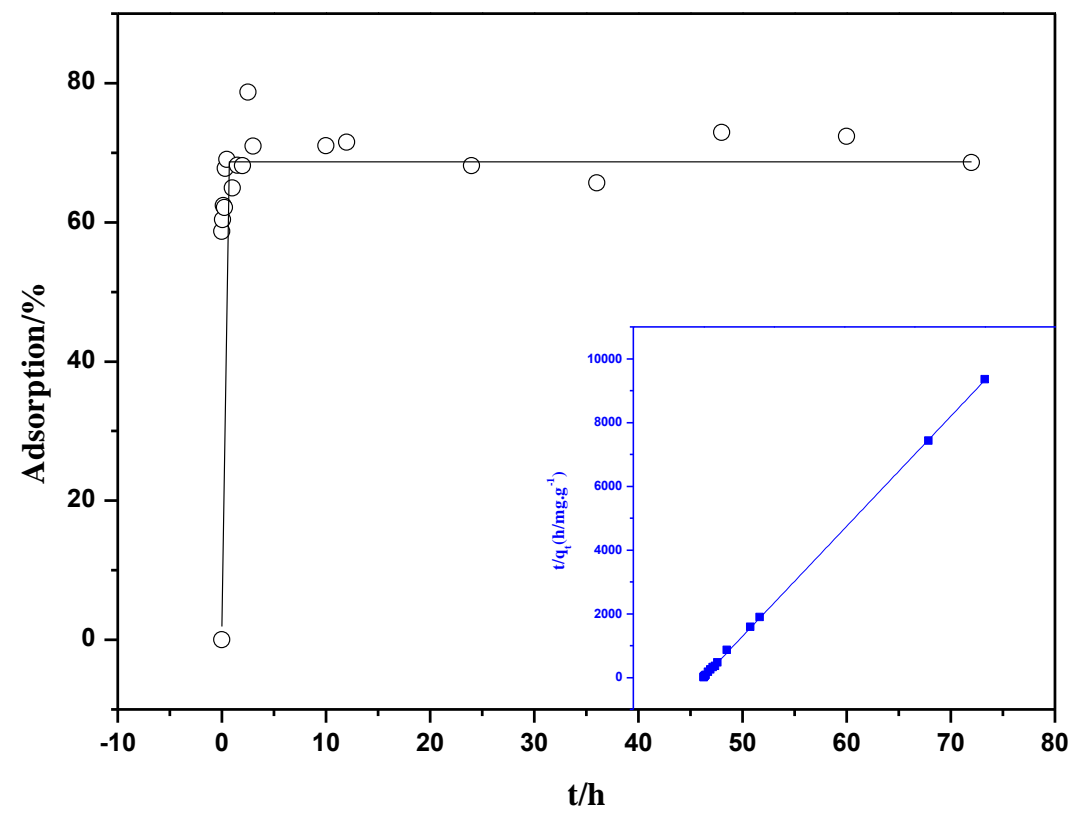

\subsubsection{Influence of $\mathrm{pH}$ and Ionic Strength}

The $\mathrm{pH}$ of solution is a controlling factor in Th(IV) adsorption experiments. Figure 5 shows the effect of $\mathrm{pH}$ on $\mathrm{Th}(\mathrm{IV})$ removal by varying the $\mathrm{pH}$ from 1 to 10 in $0.001,0.01$ and $0.1 \mathrm{~mol} \cdot \mathrm{L}^{-1} \mathrm{NaNO}_{3}$ solution. As shown in Figure 5, Th(IV) adsorption is strongly influenced by the solution $\mathrm{pH}$ values. As $\mathrm{pH}$ increased from 1 to 4, the fraction of Th(IV) adsorbed onto oMWCNTs also increased, and then the adsorption of $\mathrm{Th}(\mathrm{IV})$ maintains at the maximum value of $92 \%$ after $\mathrm{pH} \geq 4$. The maximum adsorption in the $\mathrm{pH}$ range 3-4 may be due to the formation of $\mathrm{Th}(\mathrm{IV})$ complexes with carboxyl groups on the surface of oMWCNTs. It is well known that oxidation of carbon surface can offer not only more hydrophilic surface structure, but also a large number of oxygen-containing functional groups like $-\mathrm{COOH},-\mathrm{OH}$, or $-\mathrm{C}=\mathrm{O}$ on the surfaces of oMWCNTs, which increase the sorption capability of carbon material [5]. The results are similar to the Th(IV) adsorption on anatase [30] and silica [31]. The increase of Th(IV) adsorption on oMWCNTs with increasing of $\mathrm{pH}$ may be attributed to the 
surface properties of oMWCNTs in terms of surface charge and dissociation of functional groups [32]. The surface of oMWCNTs contains a large number of binding sites, which may become positively charged at low $\mathrm{pH}$ due to the protonation reaction on the surfaces (i.e., $\mathrm{SOH}+\mathrm{H}^{+} \Leftrightarrow \mathrm{SOH}_{2}^{+}$). The point of zero charge $\left(\mathrm{pH}_{\mathrm{pzc}}\right)$ of oMWCNTs is about 5 [6,33]. At $\mathrm{pH}<5$, the surfaces were positively charged, and at $\mathrm{pH}>5$, the surface were negatively charged. The electrostatic repulsion occurred between Th(IV) and the edge groups with positive charge $\left(\mathrm{SOH}_{2}{ }^{+}\right)$on oMWCNTs surface results in the low adsorption efficiency of Th(IV). At high $\mathrm{pH}$ values, the surface of oMWCNTs becomes negatively charged due to the deprotonation process (i.e., $\mathrm{SOH} \Leftrightarrow \mathrm{SO}^{-}+\mathrm{H}^{+}$) and electrostatic repulsion decreases with increasing of $\mathrm{pH}$ because of the reduction of positive charge density on the adsorption edges, which enhances the adsorption of the positively charged $\mathrm{Th}(\mathrm{IV})$ ions through electrostatic attraction. The characteristic of Th(IV) complex that predominates at a specific solution pH may also play an important role in the uptake efficiency of oMWCNTs for Th(IV) adsorption [34]. According to the hydrolysis constants of Th(IV) $\left(\log k_{1}=-3.86, \log k_{2}=-11.82, \log k_{3}=-24.81\right.$, $\left.\log k_{4}=-41.97\right)[35,36], \mathrm{Th}(\mathrm{IV})$ species present in the forms of $\mathrm{Th}^{4+}, \mathrm{Th}(\mathrm{OH})^{3+}, \mathrm{Th}(\mathrm{OH})_{2}{ }^{2+}$, $\mathrm{Th}(\mathrm{OH})_{3}{ }^{3+}, \mathrm{Th}(\mathrm{OH})_{4}$ at different $\mathrm{pH}$ values. As can be seen from Figure 5, it is clear that Th(IV) starts to form precipitation at $\mathrm{pH}=3.85$ if no $\mathrm{Th}(\mathrm{IV})$ is adsorbed on oMWCNTs. However, one can see that more than $90 \% \mathrm{Th}(\mathrm{IV})$ has been adsorbed onto oMWCNTs at $\mathrm{pH}<3.85$. Therefore, the abrupt increasing of Th(IV) adsorption is not attributed to the precipitation of $\mathrm{Th}(\mathrm{OH})_{4}(\mathrm{~s})$. Sheng et al. [37] studied the adsorption of Th(IV) on alumina and they did not think the precipitation is the removal mechanism of alumina toward Th(IV) at $\mathrm{pH}<4$. They pointed out that the high adsorption of Th(IV) on the surface of oMWCNTs may result in the precipitation of Th(IV) on oMWCNTs due to the local high concentration of Th(IV) on oMWCNTs surface $[38,39]$.

Figure 5. Adsorption of Th(IV) on oMWCNTs as a function of $\mathrm{pH}, m / V=0.1 \mathrm{~g} / \mathrm{L}$, $T=25 \pm 1{ }^{\circ} \mathrm{C}, \mathrm{C}\left[\mathrm{Th}^{4+}\right]$ initial $=8.86 \times 10^{-5} \mathrm{~mol} / \mathrm{L}$.

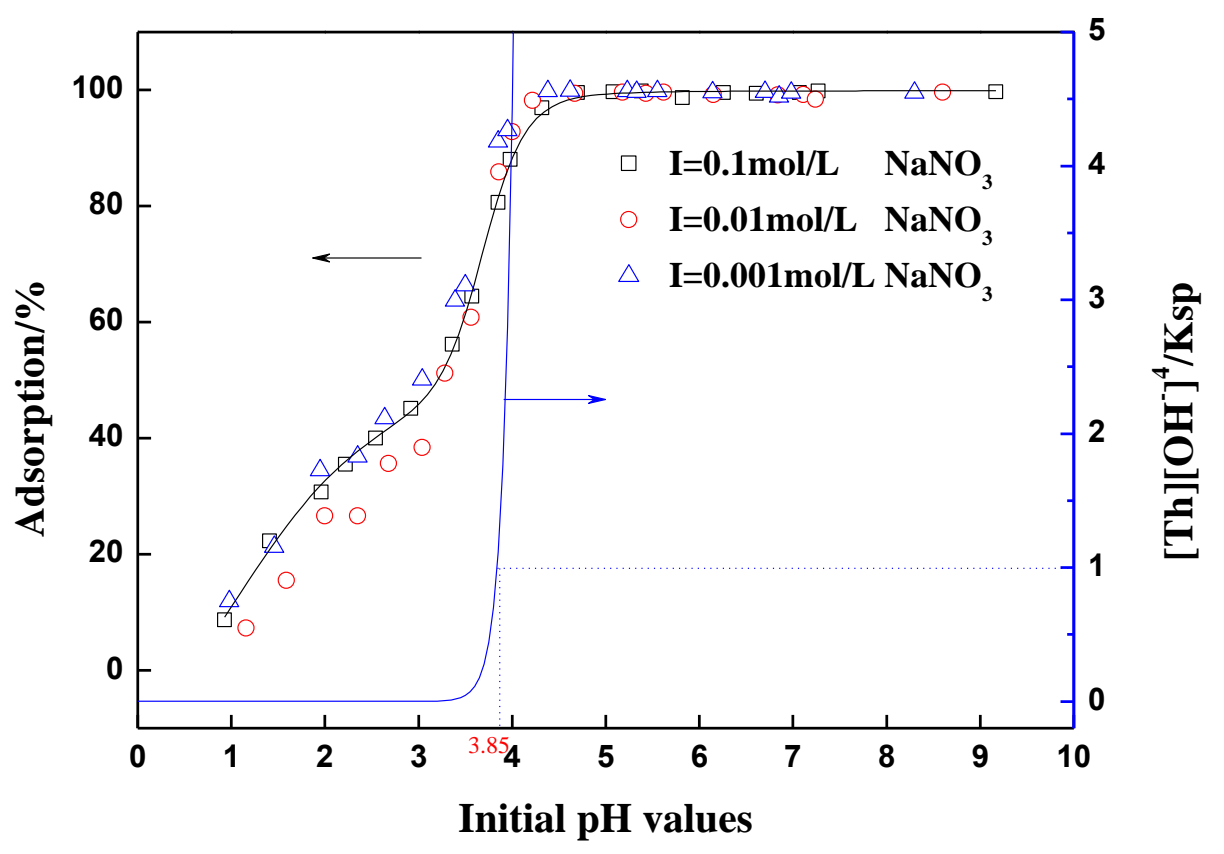


Figure 5 also shows the adsorption of Th(IV) onto oMWCNTs as a function of ionic strength at $\mathrm{pH} 1-10$. Th(IV) adsorption is independent of the ionic strength, which suggests that inner-sphere surface complexes has been formed under this experimental condition [6,11]. Therein, ion exchange does not contribute to the adsorption of Th(IV) onto oMWCNTs. In general, strong dependency on $\mathrm{pH}$ and weak dependency on ionic strength, are consistent with inner-sphere complexation [40]. The results of this work are identical to those derived from the literature [12,13,41], although different adsorbate or adsorbents are investigated in the present work.

\subsubsection{Influence of the Concentration of oMWCNTs}

Adsorption of Th(IV) as a function of oMWCNTs content is shown in Figure 6. The distribution coefficient $\left(K_{d}\right)$ was calculated from the initial concentration of $\mathrm{Th}(\mathrm{IV})\left(C_{0}\right)$ and the equilibrium one $\left(C_{e}\right)$ according to the following equation:

$$
k_{d}=\frac{C_{0}-C_{e}}{C_{0}} \times \frac{V}{m}
$$

where $V$ is the volume of the solution and $m$ is the mass of oMWNCTs. One can see that the sorption percentage of Th(IV) increases with increasing content of oMWCNTs in the system. The functional sites on oMWCNTs surfaces increase with increasing of oMWCNTs content, therefore the sorption percentage of Th(IV) increases reasonably. However, the $K_{d}$ value increases slightly with increasing content of oMWCNTs. The results of this work are very similar to the literature [42].

Figure 6. Effect of solid content on the adsorption of Th(IV) onto oMWCNTs, $\mathrm{pH}=3.20 \pm 0.05, T=25 \pm 1{ }^{\circ} \mathrm{C}, \mathrm{C}\left[\mathrm{Th}^{4+}\right]$ initial $=8.86 \times 10^{-5} \mathrm{~mol} / \mathrm{L}$, $I=0.01 \mathrm{~mol} / \mathrm{L} \mathrm{NaNO}_{3}$.

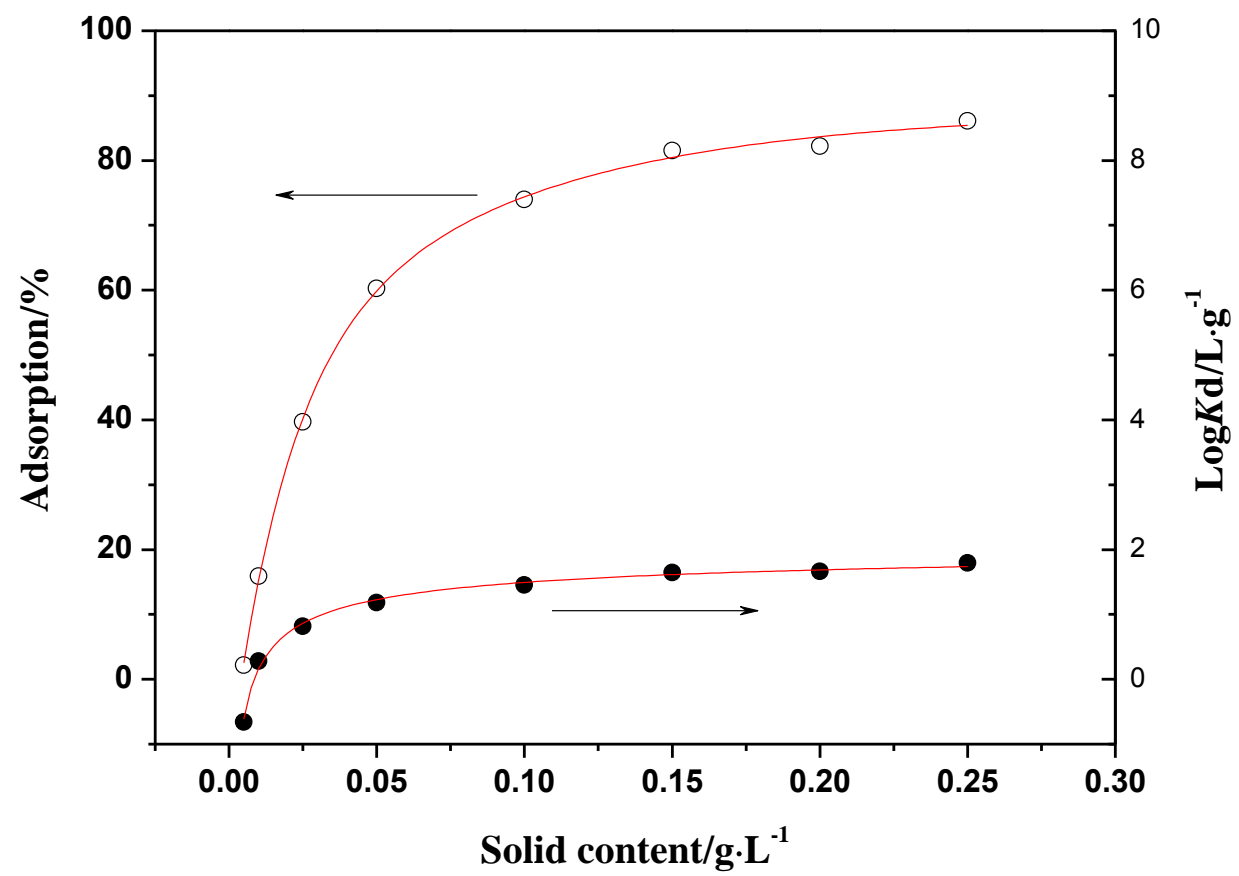




\subsubsection{Adsorption Isotherms}

The effect of temperature on the adsorption of Th(IV) was studied by performing a series of experiments at 298,318 and $338 \mathrm{~K}$. The concentration of Th(IV) varied from 0 to $8.86 \times 10^{-4} \mathrm{~mol} / \mathrm{L}$. Figure 7 shows the Th(IV) adsorption isotherm on oMWCNTs. The Langmuir model and Freundlich model were used to analyze regressively the adsorption isotherms of $\mathrm{Th}(\mathrm{IV})$. The linear form of the Langmuir model can be represented by the following equation:

$$
\frac{C_{e}}{q_{e}}=\frac{1}{K_{L} q_{\max }}+\frac{C_{e}}{q_{\max }}
$$

where $q_{e}(\mathrm{mg} / \mathrm{g})$ and $C_{e}(\mathrm{mg} / \mathrm{L})$ are respectively for the concentration of the metal ions in the solid and liquid phases in equilibrium adsorption, $K_{L}(\mathrm{~L} / \mathrm{g})$ is the adsorption equilibrium constant, $q_{\max }(\mathrm{mg} / \mathrm{g})$ is the maximum adsorption capacity of the metal ion.

The Freundlich isotherm has the following linear form:

$$
\log q_{e}=\log K_{F}+n \log C_{e}
$$

where $q_{e}(\mathrm{mg} / \mathrm{g})$ represents the adsorption amount of the metal ions in the unit mass of oMWCNTs; $C_{e}(\mathrm{mg} / \mathrm{L})$ is the equilibrium aqueous concentration; $K_{F}$ and $n$ are the absorption capacity and strength in the Freundlich the equilibrium constants, respectively.

Figure 7. Adsorption isotherms of Th(IV) on oMWCNTs at three different temperatures, $m / V=0.1 \mathrm{~g} / \mathrm{L}, \mathrm{pH}=3.20 \pm 0.05, I=0.01 \mathrm{~mol} / \mathrm{L} \mathrm{NaNO}_{3}, \mathrm{C}\left[\mathrm{Th}^{4+}\right]$ initial $=8.86 \times 10^{-5} \mathrm{~mol} / \mathrm{L}$.

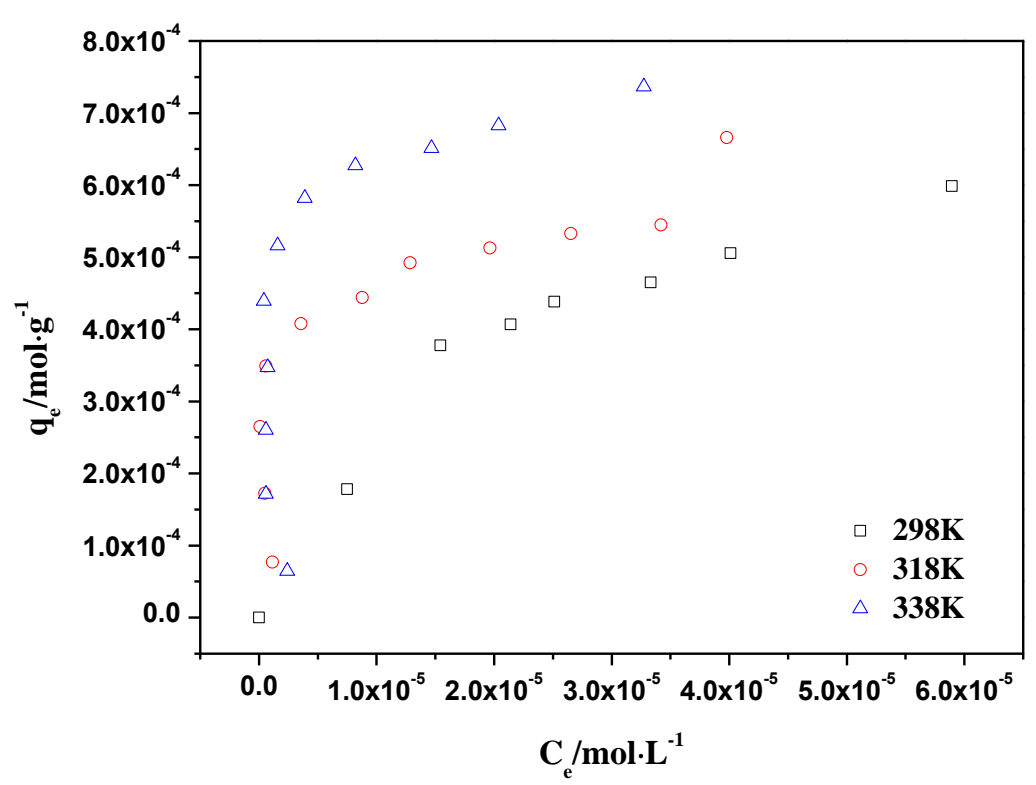

The linearized Langmuir and Freundlich plots are shown in Figures 8 and 9. Parameter values for two kinds of models are presented in Table 1. The Langmuir model showed a higher correlation coefficient than the Freundlich model. This is consistent with the results in the literature, which shows that the adsorption of Th(IV) on the other materials meet the Langmuir model better [43]. The thermodynamic parameters of $\Delta H^{0}, \Delta G^{0}$ and $\Delta S^{0}$ calculated from different adsorption isotherms are tabulated in Table 2. The $\Delta H^{0}$ value was positive as expected for an endothermic reaction under the 
conditions applied. Figure 7 also confirmed that the adsorption of Th(IV) on oMWCNTs increases with increasing temperature. The negative $\Delta G^{0}$ value indicated that the adsorption process is spontaneous for Th(IV) adsorption. The decrease in $\Delta G^{0}$ with the increase of temperature exhibited more efficient adsorption at higher temperature [5].

Figure 8. Langmuir model of Th(IV) adsorption onto oMWCNTs, $m / V=0.1 \mathrm{~g} / \mathrm{L}$, $\mathrm{pH}=3.20 \pm 0.05, I=0.01 \mathrm{~mol} / \mathrm{L} \mathrm{NaNO}_{3}, \mathrm{C}\left[\mathrm{Th}^{4+}\right]$ initial $=8.86 \times 10^{-5} \mathrm{~mol} / \mathrm{L}$.

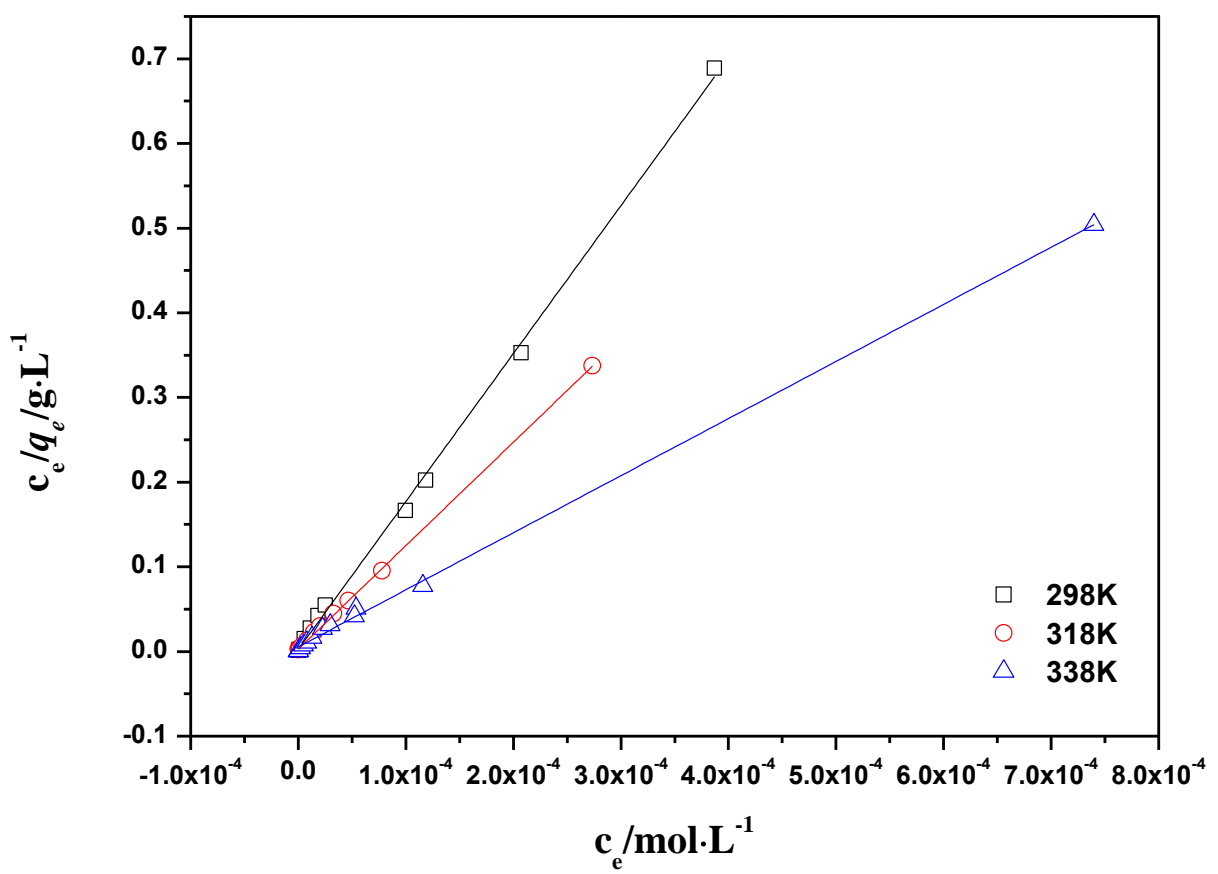

Figure 9. Freundlich model of Th(IV) adsorption onto oMWCNTs, $m / V=0.1 \mathrm{~g} / \mathrm{L}$, $\mathrm{pH}=3.20 \pm 0.05, I=0.01 \mathrm{~mol} / \mathrm{L} \mathrm{NaNO}_{3}, \mathrm{C}\left[\mathrm{Th}^{4+}\right]$ initial $=8.86 \times 10^{-5} \mathrm{~mol} / \mathrm{L}$.

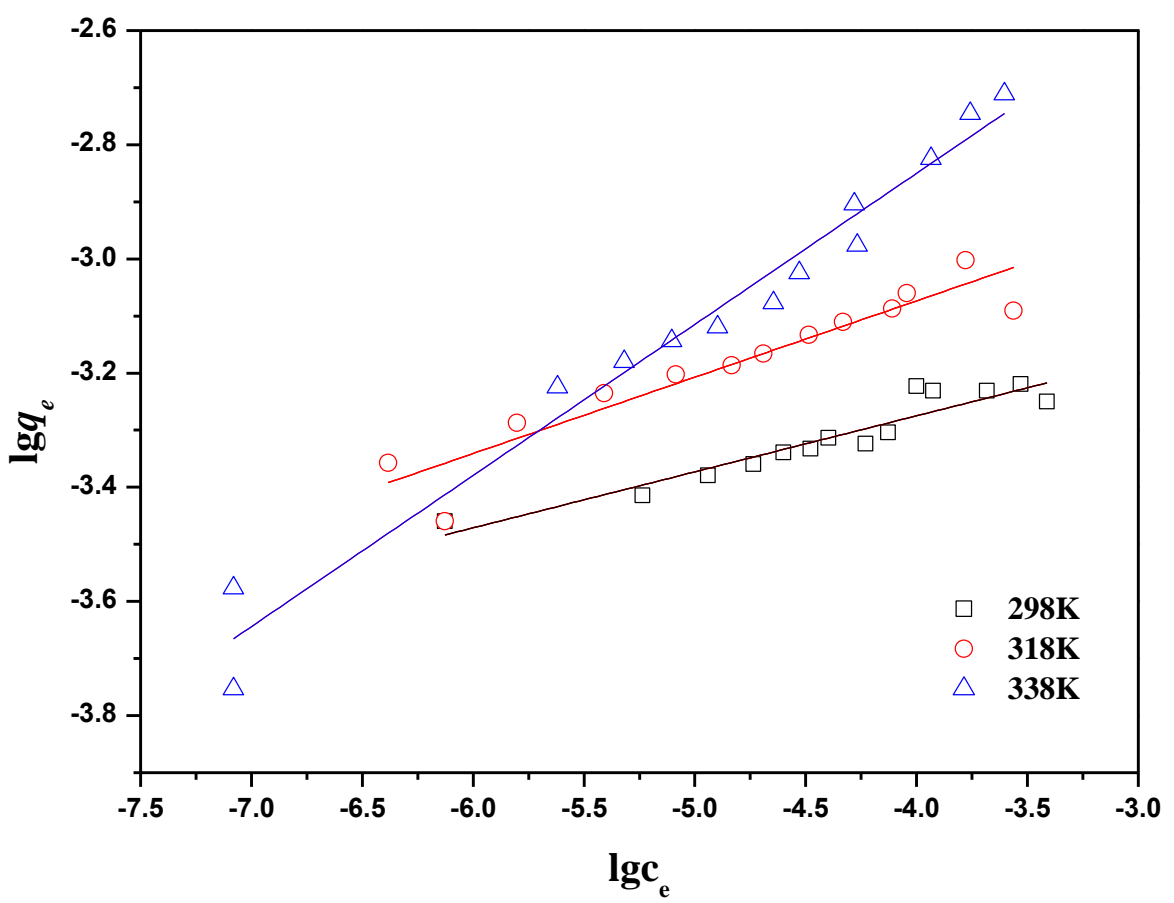


Table 1. The parameters of Langmuir and Freundlich fitting of Th(IV) adsorption on oMWCNTs.

\begin{tabular}{ccccccc}
\hline \multirow{2}{*}{$\mathbf{T}(\mathbf{K})$} & \multicolumn{3}{c}{ Langmuir constants } & \multicolumn{3}{c}{ Freundlich constants } \\
\cline { 2 - 7 } & $\boldsymbol{q}_{\max }\left(\mathbf{m g} \cdot \mathbf{g}^{-\mathbf{1}}\right)$ & $\boldsymbol{K}_{\boldsymbol{L}}$ & $\boldsymbol{R}^{\mathbf{2}}$ & $\left.\boldsymbol{K}_{\boldsymbol{F}} \mathbf{~} \mathbf{m g}^{\mathbf{1} \boldsymbol{n}} \cdot \mathbf{L}^{\mathbf{n}} \cdot \mathbf{g}^{-\mathbf{1}}\right)$ & $\boldsymbol{n}$ & $\mathbf{R}^{\mathbf{2}}$ \\
\cline { 2 - 7 } 298 & $5.72 \times 10^{-4}$ & 423.7 & 0.998 & $1.31 \times 10^{-3}$ & 0.09 & 0.887 \\
318 & $8.18 \times 10^{-4}$ & 359.7 & 0.999 & $2.89 \times 10^{-3}$ & 0.13 & 0.881 \\
338 & $1.48 \times 10^{-3}$ & 185.2 & 0.998 & $1.62 \times 10^{-3}$ & 0.26 & 0.969 \\
\hline
\end{tabular}

Table 2. Values of thermodynamic parameters for the adsorption of Th(IV) on oMWCNTs.

\begin{tabular}{|c|c|c|c|c|c|}
\hline \multirow{2}{*}{$C_{0}\left(\mathrm{mg} \cdot \mathrm{L}^{-1}\right)$} & \multirow{2}{*}{$\Delta H^{0}\left(\mathrm{KJ} \cdot \mathrm{mol}^{-1}\right)$} & \multirow{2}{*}{$\Delta S^{0}\left(\mathrm{~J} \cdot \mathrm{mol}^{-1} \cdot \mathrm{K}^{-1}\right)$} & \multicolumn{3}{|c|}{$\Delta G^{0}\left(\mathrm{KJ} \cdot \mathrm{mol}^{-1}\right)$} \\
\hline & & & 298 K & $318 \mathrm{~K}$ & $338 \mathrm{~K}$ \\
\hline $7.09 \times 10^{-5}$ & 42.65 & 168.12 & -7.19 & -11.47 & -13.84 \\
\hline $7.98 \times 10^{-5}$ & 39.52 & 154.88 & -6.53 & -10.03 & -12.69 \\
\hline $8.87 \times 10^{-5}$ & 33.67 & 134.09 & -6.17 & -9.28 & -11.51 \\
\hline $1.06 \times 10^{-4}$ & 32.15 & 125.75 & -5.17 & -8.23 & -10.15 \\
\hline
\end{tabular}

\subsection{Influence of $\mathrm{C}_{60}(\mathrm{OH})_{n}$ on the Adsorption of Th(IV)}

2.3.1. Adsorption of $\mathrm{Th}(\mathrm{IV})$ vs. $\mathrm{pH}$ in the Presence of $\mathrm{C}_{60}(\mathrm{OH})_{n}$

Figure10 presents Th(IV) adsorption onto oMWCNTs in the absence and presence of $\mathrm{C}_{60}(\mathrm{OH})_{n}$ as a function of $\mathrm{pH}$ values. The concentration of $\mathrm{C}_{60}(\mathrm{OH})_{n}$ is fixed from 10 to $250 \mathrm{mg} / \mathrm{L}$. The adsorption curve of Th(IV) in ternary system presented in Figure 10 can be divided into two different parts. Within the first region $(1 \leq \mathrm{pH} \leq 4)$, the adsorption of $\mathrm{Th}(\mathrm{IV})$ increases with increasing $\mathrm{pH}$ in the presence of $\mathrm{C}_{60}(\mathrm{OH})_{n}$. However, the adsorption hindrance of $\mathrm{Th}(\mathrm{IV})$ appears in the presence of high concentration of $\mathrm{C}_{60}(\mathrm{OH})_{n}$ (i.e., 125 and $250 \mathrm{mg} / \mathrm{L}$ ) at $\mathrm{pH}$ 4. The second region lies where the adsorption of Th(IV) markedly decreases with increasing $\mathrm{pH}$ when $\mathrm{pH}$ exceeds 4 in ternary system. A striking observation can be made that the decreases of Th(IV) adsorption is correlated strongly to the concentration of $\mathrm{C}_{60}(\mathrm{OH})_{n}$. The adsorption curve of Th(IV) in the presence of $10 \mathrm{mg} / \mathrm{L} \mathrm{C} 60(\mathrm{OH})_{n}$ is similar to that in the absence of $\mathrm{C}_{60}(\mathrm{OH})_{n}$. When the concentration of $\mathrm{C}_{60}(\mathrm{OH})_{n}$ is $125 \mathrm{mg} / \mathrm{L}$, the adsorption of $\mathrm{Th}(\mathrm{IV})$ decreases from approximate $83 \%$ at $\mathrm{pH} 4$ to $20 \%$ at $\mathrm{pH} 8.5$. While the adsorption of Th(IV) decreases from nearly $63 \%$ at $\mathrm{pH} 4$ to $3 \%$ at $\mathrm{pH} 8.5$ when $250 \mathrm{mg} / \mathrm{L} \mathrm{C}_{60}(\mathrm{OH})_{n}$ is added. It can be stated that $\mathrm{C}_{60}(\mathrm{OH})_{n}$ impedes obviously the adsorption of Th(IV) onto oMWCNTs. These observations are not in agreement with the general behavior of Th(IV) in natural systems, which are associated with organic matter [17,44-46].

The decreases of Th(IV) adsorption on oMWCNTs may be explained by a competition between $\mathrm{C}_{60}(\mathrm{OH})_{n}$ and $\mathrm{Th}(\mathrm{IV})$ for the sorption sites on the oMWCNTs surface. Both the adsorption of Th(IV) and $\mathrm{C}_{60}(\mathrm{OH})_{n}$ occurred on the surface of oMWCNTs, whereas Th(IV) cannot interact with $\mathrm{C}_{60}(\mathrm{OH})_{n}$. In other words, $\mathrm{C}_{60}(\mathrm{OH})_{n}$-oMWCNTs and Th-oMWCNTs complexes can be formed but $\mathrm{C}_{60}(\mathrm{OH})_{n}$-Th may not formed. Figure 1B confirms that the adsorption of $\mathrm{C}_{60}(\mathrm{OH})_{n}$ takes place onto oMWCNTs. Figure A1 demonstrates that the zeta potential of oMWCNTs in solution decreases regularly with increasing concentration of $\mathrm{C}_{60}(\mathrm{OH})_{n}$. This verified that the dispersivity of oMWCNTs in solution has been improved by adsorbed $\mathrm{C}_{60}(\mathrm{OH})_{n}$. The adsorption of $\mathrm{C}_{60}(\mathrm{OH})_{n}$ on oMWCNTs depends on the strong $\pi-\pi$ electron donor-acceptor interactions between the flat surfaces of both aromatic $\mathrm{C}_{60}(\mathrm{OH})_{n}$ 
and oMWCNTs [47]. The complexation between $\mathrm{C}_{60}(\mathrm{OH})_{n}$ and oMWCNTs is stronger than that between Th(IV) and oMWCNTs. Adsorbed $\mathrm{C}_{60}(\mathrm{OH})_{n}$ may block available sites of oMWCNTs surface which would be originally for the adsorption of Th(IV) [31]. With increasing $\mathrm{pH}$, Th(IV) would be "squeezed" down by the increasing adsorption of $\mathrm{C}_{60}(\mathrm{OH})_{n}$ on oMWCNTs due to the enhancement of space hindrance.

Figure 10. Effect of $\mathrm{C}_{60}(\mathrm{OH})_{n}$ on Th(IV) adsorption onto oMWCNTs as a function of $\mathrm{pH}$, $m / V=0.1 \mathrm{~g} / \mathrm{L}, T=25 \pm 1^{\circ} \mathrm{C}, I=0.01 \mathrm{~mol} / \mathrm{L} \mathrm{NaNO}_{3}, \mathrm{C}\left[\mathrm{Th}^{4+}\right]$ initial $=8.86 \times 10^{-5} \mathrm{~mol} / \mathrm{L}$.

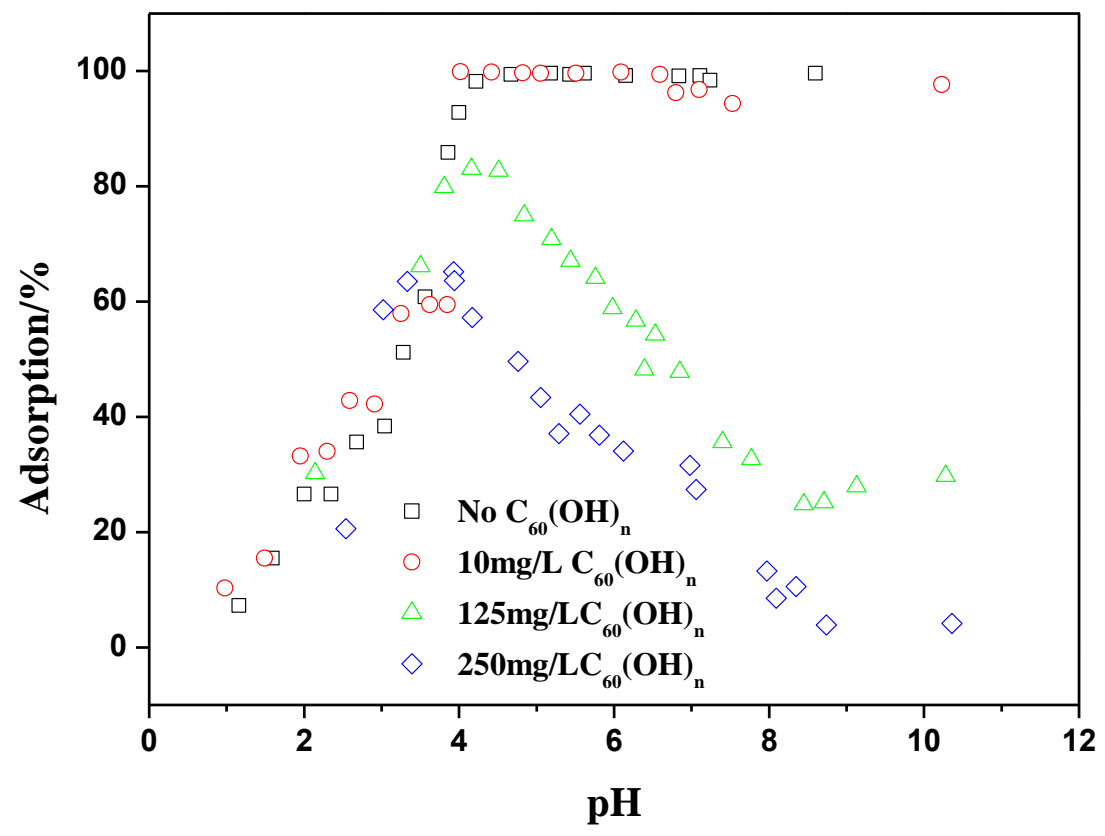

From Figure 10, one can still see that at $\mathrm{pH}>9, \mathrm{Th}(\mathrm{IV})$ adsorption rises again slightly, which could be due to following factors: at $\mathrm{pH}>9, \mathrm{Th}(\mathrm{OH})_{3}\left(\mathrm{CO}_{3}\right)^{-}$and $\mathrm{Th}\left(\mathrm{CO}_{3}\right)_{5}{ }^{6-}$ is expected to begin forming and $\mathrm{Th}(\mathrm{OH})_{4}$ is the predominating species. Adsorbed $\mathrm{C}_{60}(\mathrm{OH})_{n}$ on oMWCNTs surface enhances electrostatic repulsion of the $\mathrm{Th}(\mathrm{OH})_{3}\left(\mathrm{CO}_{3}\right)^{-}$and $\mathrm{Th}\left(\mathrm{CO}_{3}\right)_{5}{ }^{6-}$ [31]. In general, the adsorption behavior of $\mathrm{Th}(\mathrm{IV})$ in the presence of $\mathrm{C}_{60}(\mathrm{OH})_{n}$ may be described as a competition between $\mathrm{Th}(\mathrm{IV})$ and $\mathrm{C}_{60}(\mathrm{OH})_{n}$ for the binding sites on the surface of oMWCNTs. Adsorbed $\mathrm{C}_{60}(\mathrm{OH})_{n}$ may also affect the adsorption of Th(IV) by altering surface charges and/or blocking available sites binding Th(IV). This assumption was not verified, and further work is in progress.

\subsubsection{Adsorption Isotherms at Constant Adsorbent Dose and Initial Concentration}

Adsorption experiments have been conducted at constant concentrations of Th(IV) and ratio of solid to liquid as a function of $\mathrm{C}_{60}(\mathrm{OH})_{n}$ concentration (as shown in Figures 11 and 12). The $\mathrm{C}_{60}(\mathrm{OH})_{n}$ concentration varied from 0 to $250 \mathrm{mg} / \mathrm{L}$. In a general manner, Th(IV) adsorption onto oMWCNTs decreases when $\mathrm{C}_{60}(\mathrm{OH})_{n}$ concentration increases whatever the concentrations of $\mathrm{Th}(\mathrm{IV})$ and ratio of solid to liquid is. The adsorption isotherms reveals a similar behavior as can be seen from Figures 10 and 11 shows that Th(IV) adsorption decreases by half with the initial concentration of Th(IV) decreasing by half, indicating that $\mathrm{Th}(\mathrm{IV})$ does not interact with $\mathrm{C}_{60}(\mathrm{OH})_{n}$. Figure 12 presents that when the dosage of oMWCNTs are 0.2 and $0.1 \mathrm{~g} / \mathrm{L}$ and the concentration of $\mathrm{C}_{60}(\mathrm{OH})_{n}$ is less than 
$100 \mathrm{mg} / \mathrm{L}$, the adsorption of Th(IV) on oMWCNTs maintains stable at a high level, then falls sharply when the concentration of $\mathrm{C}_{60}(\mathrm{OH})_{n}$ exceeds $100 \mathrm{mg} / \mathrm{L}$. As the dosage of oMWCNTs is $0.05 \mathrm{~g} / \mathrm{L}$, $\mathrm{Th}(\mathrm{IV})$ adsorption decreases gradually when the concentration of $\mathrm{C}_{60}(\mathrm{OH})_{n}$ is more than $100 \mathrm{mg} / \mathrm{L}$ and remains at a minimum value of $\sim 25 \%$. This may be demonstrates indirectly the adsorption of $\mathrm{C}_{60}(\mathrm{OH})_{n}$ on oMWCNTs.

Figure 11. Effect of Th(IV) initial concentrations on Th(IV) adsorption onto oMWCNTs as a function of $\mathrm{C}_{60}(\mathrm{OH})_{n}$ initial concentrations, $m / V=0.1 \mathrm{~g} / \mathrm{L}, \mathrm{pH}=3.20 \pm 0.05$, $I=0.01 \mathrm{~mol} / \mathrm{L} \mathrm{NaNO}_{3}, T=25 \pm 1{ }^{\circ} \mathrm{C}$.

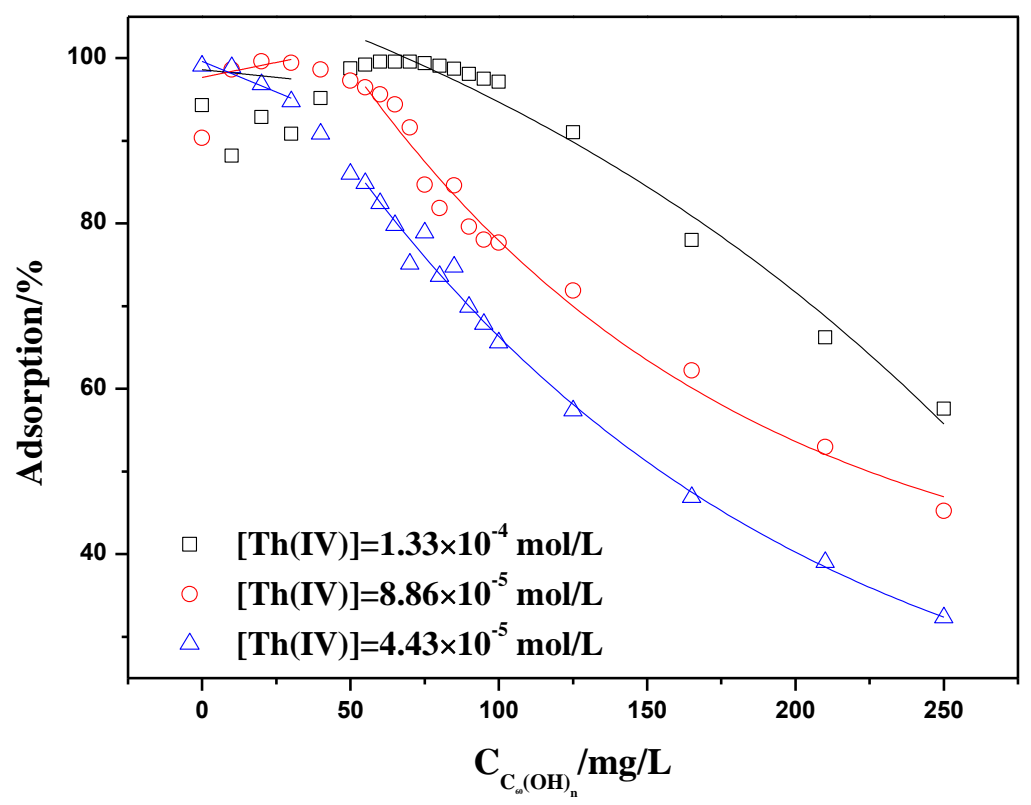

Figure 12. Effect of oMWCNT dosage on Th(IV) adsorption on oMWCNTs as a function of $\mathrm{C}_{60}(\mathrm{OH})_{n}$ initial concentrations, $\mathrm{pH}=3.20 \pm 0.05, I=0.01 \mathrm{~mol} / \mathrm{L} \quad \mathrm{NaNO}_{3}$, $T=25 \pm 1{ }^{\circ} \mathrm{C}, \mathrm{C}\left[\mathrm{Th}^{4+}\right]$ initial $=8.86 \times 10^{-5} \mathrm{mg} / \mathrm{L}$.

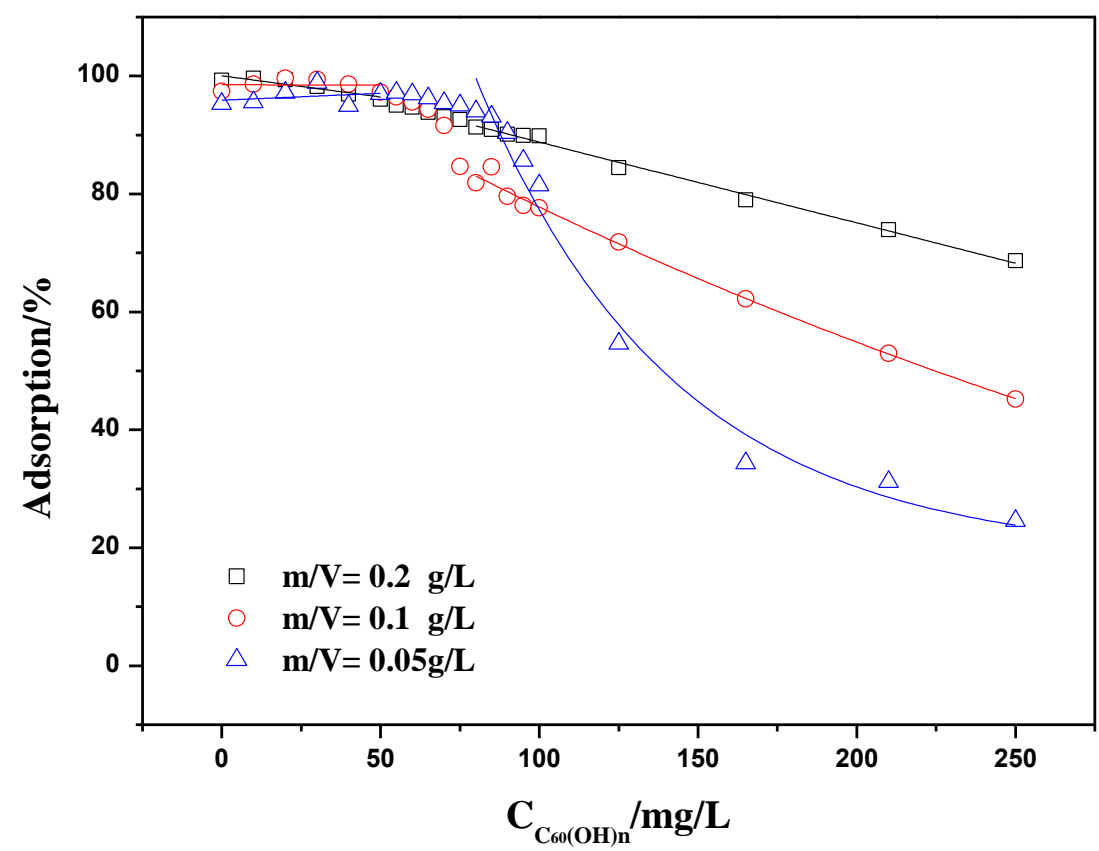


Both of the experimental curves in Figures 11 and 12 can be divided into two distinct regions. In the first region, where the concentration of $\mathrm{C}_{60}(\mathrm{OH})_{n}$ is lower than $50 \mathrm{mg} / \mathrm{L}, \mathrm{Th}(\mathrm{IV})$ adsorption is more than $90 \%$; In the second region, where the concentration of $\mathrm{C}_{60}(\mathrm{OH})_{n}$ is higher than $50 \mathrm{mg} / \mathrm{L}$, the adsorption of Th(IV) onto oMWCNTs is decreased with increasing $\mathrm{C}_{60}(\mathrm{OH})_{n}$ concentration. That is to say, $\mathrm{C}_{60}(\mathrm{OH})_{n}$ suppresses the $\mathrm{Th}(\mathrm{IV})$ adsorption when its concentration exceeds a critical value.

\subsection{Influence of $\mathrm{C}_{60}\left(\mathrm{C}(\mathrm{COOH})_{2}\right)_{n}$ on $\mathrm{Th}(\mathrm{IV})$ Adsorption}

Figure 13 exhibits the adsorption of Th(IV) on oMWCNTs as a function $\mathrm{pH}$ in the presence and absence of $\mathrm{C}_{60}\left(\mathrm{C}(\mathrm{COOH})_{2}\right)_{n}$. The adsorption curve of Th(IV) onto oMWCNTs in the presence of $\mathrm{C}_{60}\left(\mathrm{C}(\mathrm{COOH})_{2}\right)_{n}$ shifts to the left as compared to that in the absence of $\mathrm{C}_{60}\left(\mathrm{C}(\mathrm{COOH})_{2}\right)_{n}$ at $\mathrm{pH}<4$, from which it can be concluded that the presence of $\mathrm{C}_{60}\left(\mathrm{C}(\mathrm{COOH})_{2}\right)_{n}$ enhances $\mathrm{Th}(\mathrm{IV})$ adsorption at $\mathrm{pH}<4$. Moreover, the adsorption of $\mathrm{Th}(\mathrm{IV})$ increases with increasing of $\mathrm{C}_{60}\left(\mathrm{C}(\mathrm{COOH})_{2}\right)_{n}$ concentration. It can conjectured that the complexation between $\mathrm{C}_{60}\left(\mathrm{C}(\mathrm{COOH})_{2}\right)_{n}$ and $\mathrm{Th}(\mathrm{IV})$ is formed. The complexes may promote the precipitation of Th(IV) on the surface of oMWCNTs [37]. Therefore $\mathrm{Th}(\mathrm{IV})$ adsorption on oMWCNTs is enhanced in the presence of $\mathrm{C}_{60}\left(\mathrm{C}(\mathrm{COOH})_{2}\right)_{n}$ in ternary system. But with increasing of $\mathrm{pH}$, one can see that $\mathrm{Th}(\mathrm{IV})$ adsorption reduces slightly at intermediate $\mathrm{pH}(\sim 4-6)$ and then rises again until equilibrium at $\mathrm{pH}>6$. This also indicates that the negative effect of $\mathrm{C}_{60}\left(\mathrm{C}(\mathrm{COOH})_{2}\right)_{n}$ on $\mathrm{Th}(\mathrm{IV})$ sorption is different from that of $\mathrm{C}_{60}(\mathrm{OH})_{n}$. The steric hindered effect of $\mathrm{C}_{60}\left(\mathrm{C}(\mathrm{COOH})_{2}\right)_{n}$ is stronger than that of $\mathrm{C}_{60}(\mathrm{OH})_{n}$, and $\mathrm{C}_{60}\left(\mathrm{C}(\mathrm{COOH})_{2}\right)_{n}$ can not easily be adsorbed onto oMWCNTs like $\mathrm{C}_{60}(\mathrm{OH})_{n}$. This may be the reason why no $\mathrm{C}_{60}\left(\mathrm{C}(\mathrm{COOH})_{2}\right)_{n}$ connected to oMWCNTs surface is observed in the TEM photos of the dispersion of oMWCNTs and $\mathrm{C}_{60}\left(\mathrm{C}(\mathrm{COOH})_{2}\right)_{n}$ (seen from Figure 1C). However, $\mathrm{C}_{60}\left(\mathrm{C}(\mathrm{COOH})_{2}\right)_{n}$ can adsorbed on oMWCNTs surface due to the interaction of their functional groups at intermediate $\mathrm{pH}$, which results in the increasing space hindrance of $\mathrm{C}_{60}\left(\mathrm{C}(\mathrm{COOH})_{2}\right)_{n}$, thus reducing the $\mathrm{Th}(\mathrm{IV})$ adsorption.

Figure 13. Effect of $\mathrm{C}_{60}\left(\mathrm{C}(\mathrm{COOH})_{2}\right)_{n}$ on Th(IV) adsorption onto oMWCNTs as a function of $\mathrm{pH}, m / V=0.1 \mathrm{~g} / \mathrm{L}, T=25 \pm 1{ }^{\circ} \mathrm{C}, I=0.01 \mathrm{~mol} / \mathrm{L} \mathrm{NaNO}_{3}, \mathrm{C}\left[\mathrm{Th}^{4+}\right]$ initial $=8.86 \times 10^{-5} \mathrm{~mol} / \mathrm{L}$.

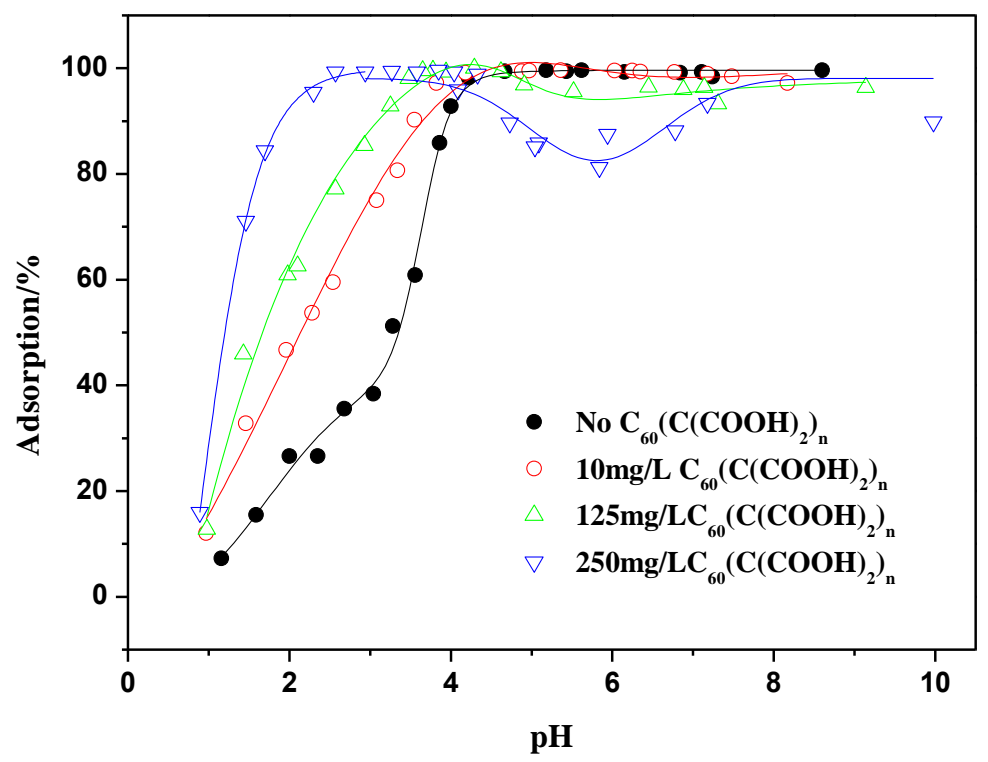




\section{Experimental Section}

\subsection{Materials}

MWCNTs (prepared by chemical vaporization deposition) were purchased from Shenzhen Nanotech Port Co., Ltd. China. According to the product specification, the as-grown MWCNTs are 1-10 $\mu \mathrm{m}$ in length, with outer diameter range of $10-30 \mathrm{~nm}$, and purity above $96 \%$ (including amorphous carbon $<3 \%$, ash $<0.2 \%$ ). Oxidized MWCNTs were prepared by oxidization with a mixture of concentrated nitric acid and sulfuric acid (1:3, V/V) [48]. The surface area of oMWCNTs is $100 \mathrm{~m}^{2} / \mathrm{g}$ determined using $\mathrm{N}_{2}$-BET method (micromeritics Surface Area and Porosity Analyzer, ASAP 2020, American). Chen et al. [49] have measured the surface area of raw carbon nanotubes and the result was $86 \mathrm{~m}^{2} / \mathrm{g}$. This indicates that the oxidation process improves the specific surface area of the MWCNTs.

Fullerenes $\left(\mathrm{C}_{60}\right)$, purity > 99\%, was bought from Henan Puyang Yongxin Fullerene Technology Co., LTD. $\mathrm{C}_{60}(\mathrm{OH})_{n}(n=2 \sim 24)$ was synthesized in the procedure reported by Li et al. [50]. Synthesis of $\mathrm{C}_{60}\left(\mathrm{C}(\mathrm{COOH})_{2}\right)_{n}$ has been described in the literature [51].

All chemicals were of analytical grade and all solutions were prepared using deionized water.

\subsection{Adsorption Experiments}

The adsorption of Th(IV) on oMWCNTs was investigated using batch technique in $10 \mathrm{~mL}$ polyethylene centrifuge tube. The stock solutions of oMWCNTs and $\mathrm{NaNO}_{3}$ were mixed and pre-equilibrated for $24 \mathrm{~h}$ and then the Th(IV) stock solution was added to achieve the desired concentrations of different components. The system was adjusted to the desired $\mathrm{pH}$ by adding negligible volumes of 0.01 or $0.1 \mathrm{~mol} \cdot \mathrm{L}^{-1} \mathrm{HNO}_{3}$ or $\mathrm{NaOH}$. After the suspensions were gently shaken for $24 \mathrm{~h}$ (which was enough to achieve equilibrium), the solid and liquid phases were separated by using centrifugating at $12,000 \mathrm{rpm}$ for $30 \mathrm{~min}$. The concentration of $\mathrm{Th}(\mathrm{IV})$ in the aqueous solution was analyzed using the thorium arsenazo(III) complex method with UV-VIS spectrophotometer (Perkin-Elmer, American) at $654 \mathrm{~nm}$. The amount of Th(IV) adsorption was calculated from the difference between the initial concentration and the equilibrium one.

Adsorption isotherms were investigated by using batch technique in polyethylene centrifuge tubes under ambient conditions at 293,313, and $333 \mathrm{~K}$, respectively. The stock solutions of $0.01 \mathrm{~mol} / \mathrm{L} \mathrm{NaNO}_{3}$ and $0.5 \mathrm{~g} / \mathrm{L}$ oMWCNTs were mixed and pre-equilibrated for $24 \mathrm{~h}$ before the addition of Th(IV) stock solution. The initial concentrations of Th(IV) varied from $8.86 \times 10^{-6}$ to $8.86 \times 10^{-4} \mathrm{~mol} / \mathrm{L}$.

The effect of $\mathrm{C}_{60}(\mathrm{OH})_{n} / \mathrm{C}_{60}\left(\mathrm{C}(\mathrm{COOH})_{2}\right)_{n}$ on the adsorption of $\mathrm{Th}(\mathrm{IV})$ was also investigated. The stock solutions of oMWCNTs and $\mathrm{C}_{60}(\mathrm{OH})_{n} / \mathrm{C}_{60}\left(\mathrm{C}(\mathrm{COOH})_{2}\right)_{n}$ and $\mathrm{NaNO}_{3}$ were mixed and pre-equilibrated for $24 \mathrm{~h}$ before adding the Th(IV) stock solution. Other procedures were the same as the single-solute sorption experiments.

\section{Conclusions}

The results of the present work indicated that chemical complexation was the main mechanism of $\mathrm{Th}(\mathrm{IV})$ adsorption onto oMWCNTs. The competition adsorption between $\mathrm{C}_{60}(\mathrm{OH})_{n}$ and Th(IV) may 
be attributed to the negative effects of $\mathrm{C}_{60}(\mathrm{OH})_{n}$ on Th(IV) adsorption onto oMWCNTs. While $\mathrm{C}_{60}\left(\mathrm{C}(\mathrm{COOH})_{2}\right)_{n}$ exhibited positive effect may be due to the fact that $\mathrm{C}_{60}\left(\mathrm{C}(\mathrm{COOH})_{2}\right)_{n}$ promoted the precipitation of Th(IV). The results are important to understand the fate and transport of Th(IV) from two kinds of carbon nano-materials and to evaluate their behavior in the environment. However, new detection method need to be developed for testing the adsorption of $\mathrm{C}_{60}(\mathrm{OH})_{n}$ and $\mathrm{C}_{60}\left(\mathrm{C}(\mathrm{COOH})_{2}\right)_{n}$ on oMWCNTs. Further systematic investigation is needed to understand fully the sorption mechanism. Such studies are continuing and will be the subject of future articles.

\section{Acknowledgments}

Financial support from National Natural Science Foundation of China (J1030932) and the "Western Light" from Chinese Academy of Sciences are acknowledged.

\section{Conflict of Interest}

The authors declare no conflict of interest.

\section{Appendix}

Figure A1. Effect of $\mathrm{C}_{60}(\mathrm{OH})_{n}$ and $\mathrm{C}_{60}\left(\mathrm{C}(\mathrm{COOH})_{2}\right)_{n}$ on the zeta potential of oMWCNTs. red line represent $\mathrm{C}_{60}(\mathrm{OH})_{n}$ effect; blue line represent $\mathrm{C}_{60}\left(\mathrm{C}(\mathrm{COOH})_{2}\right)_{n}$ effect.

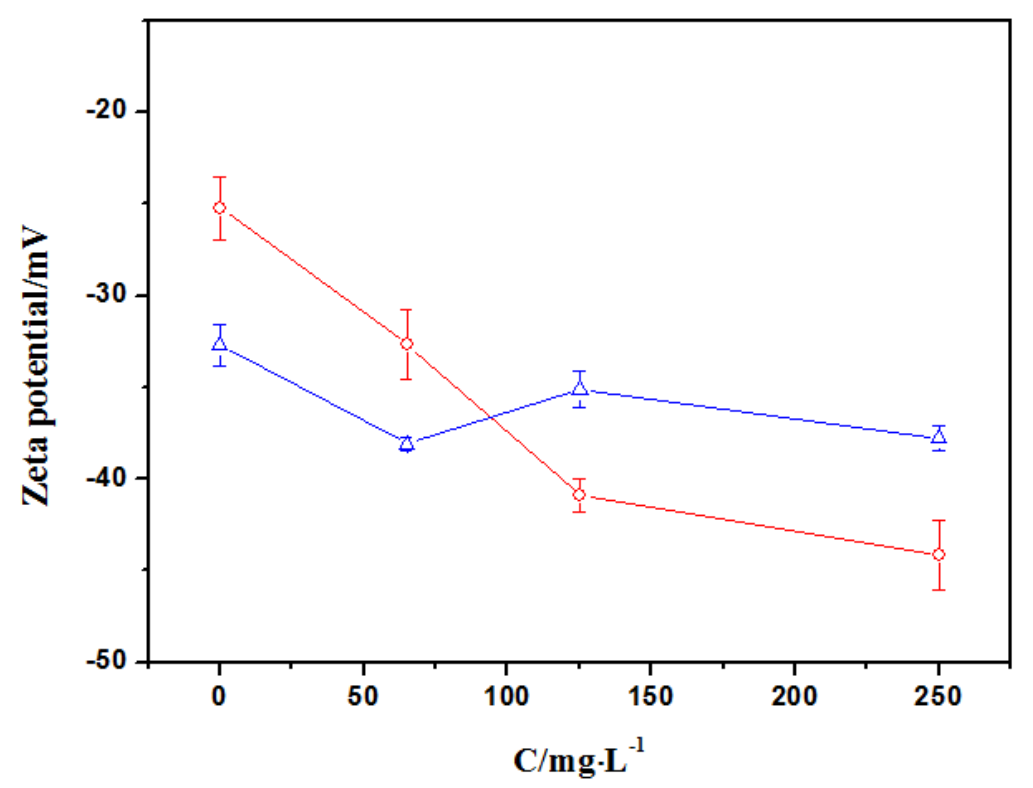

\section{References}

1. Balasubramanian, K.; Burghard, M. Chemically Functionalized Carbon Nanotubes. Small 2005, 1, 180-192.

2. Datsyuk, V.; Kalyva, M.; Papagelis, K.; Parthenios, J.; Tasis, D.; Siokou, A.; Kallitsis, I.; Galiotis, C. Chemical oxidation of multiwalled carbon nanotubes. Carbon 2008, 46, 833-840.

3. Hilding, J.; Grulke, E.A.; Zhang, Z.G.; Lockwood, F. Dispersion of carbon nanotubes in liquids. J. Disper. Sci. Technol. 2003, 24, 1-41. 
4. Hussain, C.M.; Saridara, C.; Mitra, S. Microtrapping characteristics of single and multi-walled carbon nanotubes. J. Chromatogr. A 2008, 1185, 161-166.

5. Chen, C.; Li, X.; Zhao, D.; Tan, X.; Wang, X. Adsorption kinetic, thermodynamic and desorption studies of Th(IV) on oxidized multi-wall carbon nanotubes. Colloids Surf. A Physicochem. Eng. Asp. 2007, 302, 449-454.

6. Wang, X.; Chen, C.; Hu, W.; Ding, A.; Xu, D.; Zhou, X. Sorption of ${ }^{243} \mathrm{Am}(\mathrm{III})$ to Multiwall Carbon Nanotubes. Environ. Sci. Technol. 2005, 39, 2856-2860.

7. Chen, C.; Hu, J.; Xu, D.; Tan, X.; Meng, Y.; Wang, X. Surface complexation modeling of Sr(II) and $\mathrm{Eu}(\mathrm{III})$ adsorption onto oxidized multiwall carbon nanotubes. J. Colloid Interf. Sci. 2008, 323, 33-41.

8. Nowack, B.; Bucheli, T.D. Occurrence, behavior and effects of nanoparticles in the environment. Environ. Pollut. 2007, 150, 5-22.

9. Davoren, M.; Herzog, E.; Casey, A.; Cottineau, B.; Chambers, G.; Byrne, H.J.; Lyng, F.M. In vitro toxicity evaluation of single walled carbon nanotubes on human A549 lung cells. Toxicol Vitro 2007, 21, 438-448.

10. Simon-Deckers, A.; Gouget, B.; Mayne-L'Hermite, M.; Herlin-Boime, N.; Reynaud, C.; Carrière, M. In vitro investigation of oxide nanoparticle and carbon nanotube toxicity and intracellular accumulation in A 549 human pneumocytes. Toxicology 2008, 253, 137-146.

11. Fan, Q.H.; Shao, D.D.; Hu, J.; Chen, C.; Wu, W.; Wang, X. Adsorption of humic acid and Eu (III) to multi-walled carbon nanotubes: Effect of $\mathrm{pH}$, ionic strength and counterion effect. Radiochim. Acta 2009, 97, 141-148.

12. Raju, C.S.K.; Subramanian, M. DAPPA grafted polymer: an efficient solid phase extractant for $\mathrm{U}$ (VI), Th (IV) and La (III) from acidic waste streams and environmental samples. Talanta $\mathbf{2 0 0 5}$, 67, 81-89.

13. Jain, V.; Pandya, R.; Pillai, S.; Shrivastav, P. Simultaneous preconcentration of uranium (VI) and thorium (IV) from aqueous solutions using a chelating calix[4]arene anchored chloromethylated polystyrene solid phase. Talanta 2006, 70, 257-266.

14. Aydin, F.A.; Soylak, M. Solid phase extraction and preconcentration of uranium(VI) and thorium(IV) on Duolite XAD761 prior to their inductively coupled plasma mass spectrometric determination. Talanta 2007, 72, 187-192.

15. Benkhedda, K.; Epov, V.N.; Evans, R.D. Flow-injection technique for determination of uranium and thorium isotopes in urine by inductively coupled plasma mass spectrometry. Anal. Bioanal. Chem. 2005, 381, 1596-1603.

16. östhols, E.; Manceau, A.; Farges, F.; Charlet, L. Adsorption of Thorium on Amorphous Silica: An EXAFS Study. J. Colloid Interf. Sci. 1997, 194, 10-21.

17. Chen, C.L.; Wang, X.K. Influence of $\mathrm{pH}$, soil humic/fulvic acid, ionic strength and foreign ions on sorption of thorium(IV) onto $\gamma-\mathrm{Al}_{2} \mathrm{O}_{3}$. Appl. Geochem. 2007, 22, 436-445.

18. Zuo, L.; Yu, S.; Zhou, H.; Tian, X.; Jiang, J. Th(IV) adsorption on mesoporous molecular sieves: effects of contact time, solid content, $\mathrm{pH}$, ionic strength, foreign ions and temperature. J. Radioanal. Nucl. Chem. 2011, 288, 379-387.

19. Bursali, E.A.; Merdivan, M.; Yurdakoc, M. Preconcentration of uranium (VI) and thorium (IV) from aqueous solutions using low-cost abundantly available sorbent. J. Radioanal. Nucl. Chem. 
2010, 283, 471-476.

20. Chen, C.L.; Wang, X.K.; Nagatsu, M. Europium Adsorption on Multiwall Carbon Nanotube/Iron Oxide Magnetic Composite in the Presence of Polyacrylic Acid. Environ. Sci. Technol. 2009, 43, 2362-2367.

21. Sun, Y.; Yang, S.; Sheng, G.; Guo, Z.; Wang, X. The removal of U(VI) from aqueous solution by oxidized multiwalled carbon nanotubes. J. Environ. Radioactiv. 2012, 105, 40-47.

22. Bühl, M.; Hirsch, A. Spherical aromaticity of fullerenes. Chem. Rev. 2001, 101, 1153-1183.

23. Montes-Morán, M.A.; Suárez, D.; Menéndez, J.A.; Fuente, E. On the nature of basic sites on carbon surfaces: an overview. Carbon 2004, 42, 1219-1225.

24. Avilés, F.; Cauich-Rodríguez, J.V.; Moo-Tah, L.; May-Pat, A.; Vargas-Coronado, R. Evaluation of mild acid oxidation treatments for MWCNT functionalization. Carbon 2009, 47, 2970-2975.

25. Lu, C.; Liu, C.; Rao, G.P. Comparisons of sorbent cost for the removal of $\mathrm{Ni}^{2+}$ from aqueous solution by carbon nanotubes and granular activated carbon. J. Hazard Mater. 2008, 151, 239-246.

26. Xu, J.Y.; Han, K.; Li, S.X.; Cheng, J.S.; Xu, G.T.; Li, W.X.; Li, Q.N. Pulmonary responses to polyhydroxylated fullerenols, $\mathrm{C}_{60}(\mathrm{OH})_{x}$. J. Appl. Toxicol. 2009, 29, 578-584.

27. Cheng, F.; Yang, X.; Zhu, H.; Sun, J.; Liu, Y. Synthesis of oligoadducts of malonic acid $\mathrm{C}_{60}$ and their scavenging effects on hydroxyl radical. J. Phys. Chem. Solids 2000, 61, 1145-1148.

28. Ren, X.; Wang, S.; Yang, S.; Li, J. Influence of contact time, pH, soil humic/fulvic acids, ionic strength and temperature on sorption of U(VI) onto MX-80 bentonite. J. Radioanal. Nucl. Chem. 2010, 283, 253-259.

29. Ho, Y.S. Adsorption of heavy metals from waste streams by peat. Ph.D. Dissertation, The University of Birmingham, Birmingham, UK, 1995.

30. Tan, X.; Wang, X.; Fang, M.; Chen, C. Sorption and desorption of Th(IV) on nanoparticles of anatase studied by batch and spectroscopy methods. Colloids Surf. A Physicochem. Eng. Aspects 2007, 296, 109-116.

31. Chen, C.; Wang, X. Sorption of Th (IV) to silica as a function of $\mathrm{pH}$, humic/fulvic acid, ionic strength, electrolyte type. Appl. Radiat. Isotopes 2007, 65, 155-163.

32. Zhao, D.; Sheng, G.; Hu, J.; Chen, C.; Wang, X. The adsorption of $\mathrm{Pb}(\mathrm{II})$ on $\mathrm{Mg}_{2} \mathrm{Al}$ layered double hydroxide. Chem. Eng. J. 2011, 171, 167-174.

33. Sheng, G.; Li, J.; Shao, D.; Hu, J.; Chen, C.; Chen, Y.; Wang, X. Adsorption of copper(II) on multiwalled carbon nanotubes in the absence and presence of humic or fulvic acids. J. Hazard Mater. 2010, 178, 333-340.

34. Tan, X.; Wang, X.; Chen, C.; Sun, A. Effect of soil humic and fulvic acids, pH and ionic strength on $\mathrm{Th}(\mathrm{IV})$ sorption to $\mathrm{TiO}_{2}$ nanoparticles. Appl. Radiat. Isotopes 2007, 65, 375-381.

35. Choppin, G. Actinide speciation in the environment. J. Radioanal. Nucl. Chem. 2007, 273, 695-703.

36. Anirudhan, T.S.; Rijith, S.; Tharun, A.R. Adsorptive removal of thorium(IV) from aqueous solutions using poly(methacrylic acid)-grafted chitosan/bentonite composite matrix: Process design and equilibrium studies. Colloids Surf. A Physicochem. Eng. Aspects 2010, 368, 13-22.

37. Sheng, G.; Hu, J.; Wang, X. Sorption properties of Th(IV) on the raw diatomite-Effects of contact time, $\mathrm{pH}$, ionic strength and temperature. Appl. Radiat. Isotopes 2008, 66, 1313-1320. 
38. Yang, S.; Li, J.; Lu, Y.; Chen, Y.; Wang, X. Sorption of Ni(II) on GMZ bentonite: Effects of pH, ionic strength, foreign ions, humic acid and temperature. Appl. Radiat. Isotopes 2009, 67, 1600-1608.

39. Yu, S.; Ren, A.; Cheng, J.; Song, X.; Chen, C.; Wang, X. Comparative study on sorption of radiocobalt to montmorillonite and its Al-pillared and cross-linked samples: Effect of $\mathrm{pH}$, ionic strength and fulvic acid. J. Radioanal. Nucl. Chem. 2007, 273, 129-133.

40. Bradbury, M.; Baeyens, B. Sorption of $\mathrm{Eu}$ on Na-and Ca-montmorillonites: Experimental investigations and modelling with cation exchange and surface complexation. Geochim. Cosmochim. Ac. 2002, 66, 2325-2334.

41. Wang, X.; Liu, X. Sorption and desorption of radioselenium on calcareous soil and its solid components studied by batch and column experiments. Appl. Radiat. Isotopes 2005, 62, 1-9.

42. Wu, W.; Fan, Q.; Xu, J.; Niu, Z.; Lu, S. Sorption-desorption of Th(IV) on attapulgite: Effects of $\mathrm{pH}$, ionic strength and temperature. Appl. Radiat. Isotopes 2007, 65, 1108-1114.

43. Talip, Z.; Eral, M.; Hiçsönmez, Ü. Adsorption of thorium from aqueous solutions by perlite. J. Environ. Radioactiv. 2009, 100, 139-143.

44. Reiller, P.; Moulin, V.; Casanova, F.; Dautel, C. Retention behaviour of humic substances onto mineral surfaces and consequences upon thorium (IV) mobility: case of iron oxides. Appl. Geochem. 2002, 17, 1551-1562.

45. Zhijun, G.; Lijun, N.; Zuyi, T. Sorption of $\mathrm{Th}(\mathrm{IV})$ ions onto $\mathrm{TiO}_{2}$ : Effects of contact time, ionic strength, thorium concentration and phosphate. J. Radioanal. Nucl. Chem. 2005, 266, 333-338.

46. Yu, S.M.; Chen, C.L.; Chang, P.P.; Wang, T.T.; Lu, S.S.; Wang, X.K. Adsorption of Th(IV) onto Al-pillared rectorite: Effect of $\mathrm{pH}$, ionic strength, temperature, soil humic acid and fulvic acid. Appl. Clay. Sci. 2008, 38, 219-226.

47. Chen, W.; Duan, L.; Wang, L.; Zhu, D. Adsorption of Hydroxyl- and Amino-Substituted Aromatics to Carbon Nanotubes. Environ. Sci. Technol. 2008, 42, 6862-6868.

48. Yang, S.T.; Guo, W.; Lin, Y.; Deng, X.Y.; Wang, H.F.; Sun, H.F.; Liu, Y.F.; Wang, X.; Wang, W.; Chen, M.; et al. Biodistribution of Pristine Single-Walled Carbon Nanotubes in Vivo. J. Phys. Chem. C 2007, 111, 17761-17764.

49. Chen, W.; Duan, L.; Zhu, D. Adsorption of Polar and Nonpolar Organic Chemicals to Carbon Nanotubes. Environ. Sci. Technol. 2007, 41, 8295-8300.

50. Li, T.; Li, X.; Huang, K.; Jiang, H.; Li, J. Synthesis and characterization of hydroxylated fullerene epoxide-An intermediate for forming fullerol. J. Cent. South Univ. T 1999, 6, 35-36.

51. Ye, C.; Chen, C.; Chen, Z.; Meng, H.; Xing, L.; Jiang, Y.; Yuan, H.; Xing, G.; Zhao, F.; Zhao, Y. et al. In situ observation of $\mathrm{C}_{60}\left(\mathrm{C}(\mathrm{COOH})_{2}\right)_{2}$ interacting with living cells using fluorescence microscopy. Chin. Sci. Bull 2006, 51, 1060-1064.

(C) 2013 by the authors; licensee MDPI, Basel, Switzerland. This article is an open access article distributed under the terms and conditions of the Creative Commons Attribution license (http://creativecommons.org/licenses/by/3.0/). 